\title{
Individualized Instruction in Large Classes of Integrated English in CALL Environments
}

\author{
Ping Li \\ School of Humanities, Beijing University of Posts and Telecommunications, Beijing, China \\ Email: hopejkl@yahoo.com.cn \\ Zhihong $\mathrm{Lu}$ \\ School of Humanities, Beijing University of Posts and Telecommunications, Beijing, China \\ Email: zhihonglu2002@yahoo.com.cn
}

\begin{abstract}
- this study set out to address the problem of low efficiency and effectiveness in large classes of integrated english in china's colleges. the authors of this paper converted the previous teacher-centered, one-for-all teaching in a large class of integrated english into more student-oriented, individualized instruction. first, the students were asked to make their own learning plans. second, the teacher for the study (one of the co-authors) adjusted the teaching content based on a needs analysis. and third, the teacher guided the students in autonomous learning through a learning management system (Ims) "rofall", which was co-developed by network technology engineers and college english teachers (including the authors of the paper). to evaluate this new teaching model, the authors compared students' scores on the cet-4 test with those of previous model tests and analyzed students' feedback from questionnaires and in-depth interviews. results showed students' comprehensive mastery of english was enhanced, especially in terms of vocabulary capacity, grammar knowledge, reading skills and listening ability; however, they showed a slight preference on the previous teaching model than the present one. a comparison of the two teaching models was surveyed and elaborated. the study concluded that individualized instruction based on students' needs analysis and through call environments could be a feasible way to improve efficiency and effectiveness of large class of integrated english. ways to ameliorate this model would include 1)improving students' perception of learning ; 2)training students' meta-cognitive abilities and language learning strategies; 3) the teacher's strict supervision; 4) valid assessment; and 5) understanding and support from the school administration.
\end{abstract}

Index Terms - individualized instruction, LMS, integrated English, CALL

\section{INTRODUCTION}

Teachers all over the globe are exploring ways to make teaching more efficient and effective. The first author attempted to find solutions to practical problems emerging in her Integrated English classroom. One such problem was that of class size. Given that there were over 50 students, the teacher felt compelled to use a lecture approach, making it difficult to engage students and meet their individualized needs.

In fact, research findings from the study of Integrated English class at the college level in China would suggest that teachers could be more efficient in the use of their time and more effective in their use of teaching methods. In an overview of research on large classes of College English in China in the past decade, Wang and Yan (2011, pp. 105-106) listed the problems and difficulties of such classes: 1) the underqualification of the teaching staff, 2) individual differences among students, 3) difficulties in organizing class activities with such a large group, 4) difficulties in student management, 5) lack of teacher-student communication, 6) out-of-date teaching methods, and 7) a heavy teacher workload.

In response to these issues, solutions have been proposed, including the use of CALL environments in classroom teaching (Cai, 2003; Wang et al, 2003; Nan, 2006; Jin, 2007; Wang, 2009; Xu, 2011), the emphasis on cooperative learning (Yuan, 2003; Zhang, 2007; Xu, 2011), autonomous learning (Lv, 2003; Pang, 2006; Tan \& Qiu, 2008, Wu, 2011), a communicative language teaching approach (Wen, 2003), task-based instruction (Wang, 2009), insights from Management Theory (Xiao, 2010) and so on.

These suggestions have been shown to be useful in addressing some of the issues like the organization of class activities, the improvement of teacher-student communication, and the updating of teaching methods. However, there remained one outstanding issue that was not adequately addressed in the research literature in China: the difficulty in attempting to cater to each student's individual learning needs (Yu, 2004; Xu, 2007). This paper on an empirical study intended to fill that gap. Another innovation of this paper lies in the application of an in-house language learning management system (LMS) "Rofall", which was built to rectify some problems in the existing LMS. The adoption of this new LMS was an attempt to contribute to the revisited research on the effective use of CALL environments.

\section{LITERATURE REVIEW}




\section{A. Individualized Instruction}

Individualized instruction is a method of instruction in which content, instructional technology (such as materials) and pace of learning are based upon the abilities and interests of each individual learner. It has points of contact with the constructivism movement in education, started by Swiss biologist Jean Piaget, which states that the student should build his or her learning and knowledge (Wikipedia, 2012).

In China, individualization instruction has been a classic educational principle passing down from dynasties to present times (Zhang, 2003). Typical of Confucius' way of teaching, "yin cai shi jiao", which means teaching based upon each student's individual characteristics, has been well proved to be effective. In America, almost from the inception of formal schooling, individualized programs have been developed. Over the years, the revived interest in individualization has taken a bewildering array of forms that "Individualized instruction" is considered to be a phylum rather than a species of approaches to teaching (Gibbons, 1970, p.28).

According to Gibbons (1970), individualized programs can be further divided into subgroups of instruction of individuals and that of group or class. While the first subdivision is based on how the teacher addresses his students, the second subdivision is based upon the decision-making pattern that the teacher establishes in the classroom. The features of such programs, are teacher-directed (active), teacher-student cooperation (responsive) and democratic (permissive), as demonstrated in Figure 1. In individualized instruction, the teacher should 1)be well situated between actively in control and permissive in the instructional program; and 2) plan cooperatively, and responsive to students' questions and requests in a timely manner (p.35).

Meanwhile, as language teaching has become more learner-focused and interactive, there has also been an emphasis on helping students take more responsibility for meeting their own language learning needs (Brown, 2002; Chamot, 2001; Chamot, Barnhardt, El-Dinary, \& Robbins, 1999; McDonough, 1999; Oxford, 1990, 2001; Rubin \& Thompson, 1994, quoted in Cohen \& Weaver, 1997, p. 4) . Independence, self-direction, initiative, freedom and responsibility must be developed in students (Gibbons, 1970, p. 49).

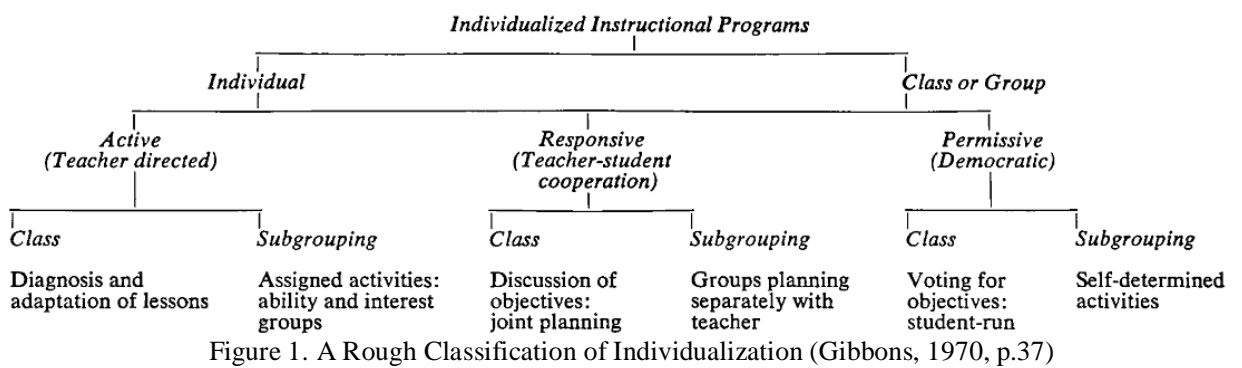

\section{B. Large Class of Integrated English in China}

Integrated English, originally called Intensive English, was proved to meet students' learning needs and social requirements in the 1980s and the early 1990s (Cai, 2007). However, it began to be notorious for "time wasting and of low teaching effects" in the late 1990s (Dai, 2001). Problems were found in terms of its teaching effects (Cai, 2003), teaching objectives, teaching model and assessment (Cai, 2005). A reform of College English was then carried out. College English was advocated to focus on students' communication skills and shift from a teacher-centered pattern to a student-centered pattern, supported by "computer- and classroom-based teaching models" (Department of Higher Education, 2007, pp. 25-26).

A class is considered to be of large size when there is over 50 students (Hayes, 1997). Large class size has been common in China: it is surveyed that the ratio of College English teachers versus students is about 1: 100 in China (Shu, 2004, p. 290), probably due to China's large population and the enlarging recruitment of college students starting from 1999. A large class size has been considered a great challenge to pedagogy. "There have been overwhelmingly positive in the belief that class size reduction leads to better student behaviour, easier classroom management and the development of more positive attitudes in learners" (Korostoff, 1998; Wang \& Finn, 2000).

\section{Needs Analysis}

Needs Analysis (NA) was defined as "the activities involved in gathering information that will serve as the basis for developing a curriculum that will meet the learning needs of a particular group of students"(Brown, 2001, p. 35). In this definition, the "learning needs" mean "a gap or measurable discrepancy between a current state of affairs and a desired future state" (Berwick, 1989, p. 52). Simply put, they are "the gap between what is and what should be" (Brindley, 1989, p. 63). NA is a vital prerequisite for developing a curriculum because "it forms a rational basis for all the other components of a systematic language curriculum" (Iwai et al, 1999, p. 7). Its importance in curriculum design has been widely recognized (Yalden, 2000; Brown, 2001; Hutchinson \& Waters, 2002; Shu, 2004; Wen, 2004; Ni and Liu, 2006).

D. CALL Environments 
CALL environments could facilitate individualized instruction, in that they makes it possible to tailor the subject matter, assessment to the individual needs of students (Volman, M. 2005, p. 18) and "permit each student to proceed at his own rate" (Skinner, 1968, p. 30), so as to facilitate differentiation and individualization in education.

\section{RESEARCH}

\section{A. Research Questions}

The two research questions for this study were:

1) How does individualized instruction improve the participating students' learning outcomes?

2) How do the teacher-centered, one-for-all lecturing model and individualized instruction model compare in terms of their relative popularity in the eyes of the students?

\section{B. Participants}

The participants consisted of 115 freshmen students (62 men, 53.4\%; 54 female, 46.6\%) of two classes in the year 2010 taught by the first author of this paper at her home university. Majored in E-commerce and Law and Telecommunication Engineering and Management, the students were from International School, where all the courses were conducted in English. They were required to finish College English courses in one year which students of other schools finished in two years. All of them had access to the Internet and were adept at using computer applications. Their English scores of National College Entrance Exam (NCEE) ranged from 87 to 140, with a mean of 126.4 (full marks: 150). Compared to the highest NCEE mean of top universities (140), lowest (around 70 to 80) and the mean of most colleges (below 100) in China (Cai, 2009a), they had a fairly excellent background in English. According to the survey, the students' motivation for learning English was mainly instrumental $(68.6 \%)$. Their dominant purpose was to get good grades in both CET-4 and final exams (32.26\%). Only $10.75 \%$ of them had Deep Motivation (They said they learnt English because they loved the language and were interested in English learning).

\section{Process}

1. Needs analysis and teaching objectives

In this study, the teacher guided the students to write down their goals in English learning at the beginning of the term. Their writings answered three questions:

1) What do I want to achieve by the end of this semester?--"What should be" (Brindley, 1989, p. 63)

2) How far away am I from that goal?--"What it is" (Brindley, 1989, p. 63)

3) How can I achieve that goal?--"How to be there".

Upon reading, the teacher commented on each student's learning objectives and guided them to make their independent study plans.

2. Reform in the teaching plan

According to students' common objectives, the teacher made a new teaching plan which increased student's autonomous learning. Before carrying out the plan, the teacher explained to the students the importance of independent study from the perspective of constructivism and gave them trainings on language learning strategies.

As demonstrated in the following table, changes of the teaching model were: previously, the teaching model was more teacher-centered and focused on students' reading abilities. These students used to have six-hour English class one week: four-hour Intensive Reading, one-hour autonomous listening practice and one-hour speaking activities. The new teaching model, on the other hand, aimed to be more student-centered and placed more emphasis on student's autonomous learning and practice of listening and speaking skills. The previous four-hour intensive reading class was condensed into two hours only, sparing two hours to be used in the computer lab instead, with one hour for speaking activities and the other for autonomous learning via a LMS "Rofall".

TABLE I.

CHANGE OF THE TEACHING MODEL OF INTEGRATED ENGLISH

\begin{tabular}{|l|l|l|l|}
\hline Previous Model & $\begin{array}{l}\text { 4-hour Intensive Reading } \\
\text { (teacher-centered) }\end{array}$ & $\begin{array}{l}\text { 1-hour speaking } \\
\text { (teaching) }\end{array}$ & $\begin{array}{l}\text { 1-hour autonomous learning } \\
\text { (mainly listening practice via a LMS "New Perspective") }\end{array}$ \\
\hline New Model & 2-hour Intensive Reading & 2-hour speaking & $\begin{array}{l}\text { 2-hour autonomous learning } \\
\text { (listening, vocabulary, writing, reading, simulated tests } \\
\text { for CET-4 and via two LMS "New Perspective" and } \\
\text { "Rofall") }\end{array}$ \\
\hline Environments & $\begin{array}{l}\text { multimedia classroom } \\
\text { (furnished with fixed tables and chairs, an } \\
\text { elevated stage and a computer, a overhead } \\
\text { projector and a blackboard in the front) }\end{array}$ & $\begin{array}{l}\text { computer lab } \\
\text { (Each student has access to a computer and the Internet if permitted; the } \\
\text { teacher's computer includes a teaching software which enables demonstration, } \\
\text { supervision, organization and recording.) }\end{array}$ \\
\hline
\end{tabular}

3. Teaching environments

The teaching was surrounded by CALL environments. In the multimedia classroom, a computer and an overhead projector were equipped. In the computer lab, computers and the Internet are available to each student. Two learning 
management systems(LMS) applied in this class were "New Perspective" and "Rofall". Rofall was more frequently used since it rectified problems in "New Perspective", which was developed earlier.

The Rofall system is an LMS co-developed by College English teachers (led by the second author of this paper) and engineers of School of Network Education at the authors' home university. To solve the problem of limited resources (mainly listening and speaking exercise) in the other LMS "New Perspective", Rofall integrates resources on more English skills, covering listening, reading, speaking and writing skills. There are 18 types of questions, including both objective questions and subjective ones (See Table ii). The system also contains model tests and authentic CET-4 exams for evaluating students' progress. As a system developed to cater to each student's needs, Rofall enables users (either the teacher or students) to select and "prescribe" different exercises and tests. Scores and detailed feedback of objective questions will be generated immediately once a test is finished. The system can also grade some subjective questions like fill-in questions and comment initially on summary writing. Yet it waits for teachers' manual grading and more detailed comments of student's composition writing. There is a discussion board where students can obtain the teacher's advice whenever necessary.

TABLE II.

EIGHTEEN TYPES OF QUESTIONS IN THE ROFALL SYSTEM

\begin{tabular}{|l|l|l|l|}
\hline No. & Objective Questions & No. & Subjective Questions \\
\hline 1 & Short Answer Questions & 10 & Rapid Question-answer Exercise \\
\hline 2 & True or False(1) & 11 & Sentence Repeat \\
\hline 3 & True or False(2) & 12 & Intonation Practice \\
\hline 4 & Multiple Choices & 13 & Personal Statement \\
\hline 5 & Spot Dictation & 14 & Group Discussion \\
\hline 6 & Sentence Dictation & 15 & Sentence Completion \\
\hline 7 & Compound Dictation & 16 & Summary Writing \\
\hline 8 & Construction Questions(1) & 17 & Essay Writing \\
\hline 9 & Constructing Questions for Given Answers (2) & 18 & Question-answer Exercise \\
\hline
\end{tabular}

\section{Teaching content}

With half of its original class time, intensive reading was conducted according to the principle of "less lecturing and more students' practice" (Sheng, 1990, p. 260). The teacher spent less time on introducing the authors of the articles in the textbook, and explained only important new words (most frequently seen and used ones) in the reading. The students were asked to preview the text and ask in class for explanations of other new words that they considered necessary.

In the additional hour of autonomous learning, students chose materials and exercise to do in the Rofall system at their own pace. The materials selected were authentic, varied, up-to-date and interesting, and arranged in the sequence of from the easy to the difficult. To guide the students through the multitude of exercises, the teacher recommended some of the exercises with a prolonged deadline. Students can decide whether, when and how much they do optional exercises according to their own English background. They may ask the teacher for guidance during the process. The teacher evaluated students' learning by both their efforts and grades, which were recorded by Rofall.

\section{Instruments}

Instruments employed in this study included data from pretests and posttests, questionnaires and interviews.

The pretests were a city-wide placement test and a Model CET 4 test, which all freshmen took at the beginning of the term. The posttests were a final exam of College English and the CET-4 exam. The questionnaires (available upon request) were designed to analyze students' motivations for learning English, perception and ability of autonomous learning, opinions on both teaching models, LMS's roles, their expected teachers' roles, etc. To reduce ambiguity, each question avoided "N/A" choice and used instead an open-ended structure "Others (please fill in____)". Interviewed were eight students at random on a voluntary basis. The interview lasted for about 15 minutes each, exploring mainly their English backgrounds, opinions on the new teaching model and their English independent learning experiences.

\section{E. Data Analysis}

The questionnaires were delivered and completed on line through the Rofall system. Out of 115 students, 96 (83.48\%) participated. All of the 96 questionnaires were collected and counted valid.

Data on students' pre- and post- test was analyzed by using SPSS 14.0:

1. Descriptive statistics (mean, variance, standard deviation, percentage) were used to analyze the scores of pretests and posttests and the answers of the questionnaires;

2. A paired sample t-test was employed to compare the students' listening abilities in both pretest and posttest. 
3. A one-sample t test was used to compare these students' placement test scores (pretest) and final exam scores (post-test) with that of the rest of the grade, so as to detect any progress they achieved if any.

\section{RESUlTS AND DisCUSSION}

\section{A. Learning Outcomes}

1. Improved comprehensive mastery of English

Good grades of CET-4 test was the students' primary goal. This goal was achieved. Compared to the mean of their Model CET4 test (493.82) at the beginning of the term, the students' scores in CET 4 after this term increased to 531.50, which is significant at .05 level (sig.=.000), as indicated in Table 1, 2 and 3.

TABLE 1.

IMPROVEMENT OF COMPREHENSIVE MASTERY OF ENGLISH (COMPARISON OF MODEL CET 4 AND CET 4 SCORES) (DESCRIPTIVE STATISTICS)

\begin{tabular}{|l|l|l|l|l|}
\hline & Mean & N & Std. Deviation & Std. Error Mean \\
\hline Pretest (ModelCET4) & 495.64 & 115 & 72.846 & 6.793 \\
\hline Posttest ( CET4) & 531.50 & 115 & 62.203 & 5.800 \\
\hline
\end{tabular}

TABLE 2.

IMPROVEMENT OF COMPREHENSIVE MASTERY OF ENGLISH (COMPARISON OF MODEL CET 4 AND CET 4 SCORES) (PAIRED SAMPLES CORRELATIONS)

\begin{tabular}{|l|l|l|l|}
\hline & N & Correlation & Sig. \\
\hline Pretest (ModelCET4) \& Posttest( CET4) & 115 & .523 & .000 \\
\hline
\end{tabular}

TABLE 3.

IMPROVEMENT OF COMPREHENSIVE MASTERY OF ENGLISH (COMPARISON OF MODEL CET 4 AND CET 4 SCORES) (PAIRED SAMPLES T TEST)

\begin{tabular}{|c|c|c|c|c|c|c|c|c|}
\hline & \multicolumn{5}{|c|}{ Paired Differences } & \multirow{3}{*}{$\mathrm{t}$} & \multirow{3}{*}{ df } & \multirow{3}{*}{ Sig. (2-tailed) } \\
\hline & \multirow[t]{2}{*}{ Mean } & \multirow{2}{*}{$\begin{array}{l}\text { Std. } \\
\text { Deviation }\end{array}$} & \multirow{2}{*}{$\begin{array}{l}\text { Std. } \\
\text { Error } \\
\text { Mean }\end{array}$} & \multicolumn{2}{|c|}{$\begin{array}{l}\text { 95\% Confidence Interval of the } \\
\text { Difference }\end{array}$} & & & \\
\hline & & & & Lower & Upper & & & \\
\hline $\begin{array}{l}\text { Pretest (ModelCET4) - } \\
\text { Posttest (CET4) }\end{array}$ & -35.852 & 66.603 & 6.211 & -48.156 & -23.549 & -5.773 & 114 & .000 \\
\hline
\end{tabular}

Since CET-4 is a national test of high validity and reliability on students' comprehensive English abilities, these results seem to evidence students' increased comprehensive mastery of English. It is also indicated that the new teaching model could be conducive to enhancing students' learning outcomes.

2. Better vocabulary capacity, grammar knowledge and reading skills

The second learning objective of the students was to improve their mastery of textbook knowledge. This goal was also realized at the end of the term. As Table 4 and 5 display, before the term started, the students sat in a city-wide placement test and scored 56.97 on average, which was lower than the mean (57.63) of the whole grade, though without significance (sig.=.5), However, after being trained in the new teaching model, the students made progress in their final exam, with the mean 83.52 above the average of all freshmen (81.38) with significance (sig.=.018).

TABLE 4.

IMPROVED MASTERY OF TEXTBOOK KNOWLEDGE (COMPARISON OF PLACEMENT TEST SCORES AND FINAL EXAM SCORES WITH THE REST OF THE GRADE) (DESCRIPTIVE STATISTICS)

\begin{tabular}{|l|l|l|l|l|}
\hline & N & Mean & Std. Deviation & Std. Error Mean \\
\hline Pretest (placement test) & 115 & 56.9741 & 10.46274 & .97144 \\
\hline Post test (final exam) & 115 & 83.2137 & 10.12579 & .93613 \\
\hline
\end{tabular}

TABLE 5

IMPROVED MASTERY OF TEXTBOOK KNOWLEDGE (COMPARISON OF PLACEMENT TEST SCORES AND FINAL EXAM SCORES WITH THE REST OF THE GRADE) (ONE-SAMPLE $T$ TEST)

\begin{tabular}{|l|l|l|l|l|l|l|}
\hline \multirow{2}{*}{} & \multicolumn{3}{|l|}{ Test Value in Pre-test =57.63202; Test Value in Post-test =81.381743 } \\
\cline { 2 - 7 } & & $\mathrm{d}$ & Sig. (2-tailed) & Mean Difference & \multicolumn{2}{|l|}{ 95\% Confidence Interval of the Difference } \\
\hline Pretest (placement test) & -.677 & 115 & .500 & -.65788 & -2.5821 & Upper \\
\hline Post test (final exam) & 2.409 & 115 & .018 & 2.14412 & .3808 \\
\hline
\end{tabular}

The final exam assessed principally the students' mastery of textbook knowledge, mainly vocabulary capacity, grammar knowledge and reading skills, which they learnt in the condensed two hours of class time per week instead of four as the rest of the grade did. This result indicates students' learning outcomes may not necessarily be in direct proportion to the teacher's lecturing time, and individualized instruction might be more efficient and effective in enhancing students' learning results.

3. Increased listening ability: 
From Table 6, 7 and 8, it is found that students' listening ability grew substantially after this term. Their listening test scores rose from 172.91 in pretest (Model CET-4 exam) to 190.84 in post-test (CET-4) with significance (sig.=.000) at .05 level.

TABLE 6.

IMPROVEMENT OF LISTENING ABILITY (COMPARISON OF MODEL CET 4 AND CET 4 SCORES) (DESCRIPTIVE STATISTICS)

\begin{tabular}{|l|l|l|l|l|}
\hline & Mean & N & Std. Deviation \\
\hline ListenPost-test (Model CET-4) & 190.8435 & 115 & 28.07402 & 2.61792 \\
ListenPre-test (CET-4) & 172.9130 & 115 & 28.02116 & 2.61299 \\
\hline
\end{tabular}

TABLE 7.

IMPROVEMENT OF LISTENING ABILITY (COMPARISON OF MODEL CET 4 AND CET 4 SCORES) (PAIRED SAMPLES CORRELATIONS)

\begin{tabular}{|l|l|l|l|}
\hline & $\mathrm{N}$ & Correlation & Sig. \\
\hline ListenPost \& ListenPre & 115 & .321 & .000 \\
\hline
\end{tabular}

TABLE 8.

IMPROVEMENT OF LISTENING ABILITY (COMPARISON OF MODEL CET 4 AND CET 4 SCORES) (PAIRED SAMPLES T TEST)

\begin{tabular}{|c|c|c|c|c|c|c|c|c|}
\hline & \multicolumn{5}{|c|}{ Paired Differences } & \multirow[t]{3}{*}{$\mathrm{t}$} & \multirow[t]{3}{*}{ df } & \multirow[t]{3}{*}{ Sig. (2-tailed) } \\
\hline & \multirow[t]{2}{*}{ Mean } & \multirow[t]{2}{*}{ Std. Deviation } & \multirow[t]{2}{*}{$\begin{array}{l}\text { Std. Error } \\
\text { Mean }\end{array}$} & \multicolumn{2}{|c|}{$\begin{array}{l}95 \% \text { Confidence Interval } \\
\text { of the Difference }\end{array}$} & & & \\
\hline & & & & Lower & Upper & & & \\
\hline ListenPost-ListenPre & 17.93043 & 32.68905 & 3.04827 & 11.89184 & 23.96903 & 5.882 & 114 & .000 \\
\hline
\end{tabular}

\section{B. The Role the LMS "Rofall" Plays in Students' Learning}

Rofall has been playing an important role in students' autonomous learning and therefore well accepted. As shown in Table 9, The majority of the students (74.2\%, a combined percentage of Choice A and B) considered Rofall very helpful, only one person voted for "not helpful", and another student who chose "others" commented that "In theory Rofall should be helpful. But I don't use it often because of heavy load of homework of other subjects. But I believe it should be very helpful if used appropriately."

TABLE. 9

IS ROFALL HELPFUL FOR YOUR ENGLISH LEARNING?

\begin{tabular}{|l|l|}
\hline Question 4. The Rofall systerm is_to your English study this term. & Percentage \\
\hline Items & $12.9 \%$ \\
\hline A. greatly helpful & $61.3 \%$ \\
\hline B. very helpful & $24.7 \%$ \\
\hline C. somewhat helpful & $1.2 \%$ \\
\hline D. not helpful & $0.0 \%$ \\
\hline E. exerting a negative effect & $1.1 \%$ \\
\hline F. Others (Please specify: & \\
\hline
\end{tabular}

Most students thought highly of the exercises in Rofall, as indicated by the combined percentage $80.7 \%$ of Choice A and B in Table 10. The reason for student' recognition lied mainly in the formative assessment nature of feedback mechanism in this system (Choice $\mathrm{C}$ and $\mathrm{B}$ in Table 11) as well as the high validity and reliability of the test, which were compiled from authentic CET-4 exam tests (Choice A, 33.3\%, in Table 11). The system also facilitated the students' use of management strategy in autonomous learning by keeping records of their learning profiles(Choice D, $29 \%$, in Table 11).

TABLE. 10

QUALITY OF THE QUESTIONS IN ROFALL

\begin{tabular}{|l|l|}
\hline Question 3. What do you think of the exercise in Rofall system in general? \\
\hline Items & Percentage \\
\hline A. very good & $41.2 \%$ \\
\hline B. all right & $20.5 \%$ \\
\hline C. not very good & $20.4 \%$ \\
\hline D. can't be worse & $0.0 \%$ \\
\hline E. others (Please specify & $0.0 \%$ \\
\hline
\end{tabular}


TABLE. 11.

REASONS FOR APPROVAL OF ROFALL

\begin{tabular}{|l|l|}
\hline Follow-up of Question 3. For those who choose A and B in question 3, the reason is (multi-answer question) \\
\hline Answer & Percentage \\
\hline $\begin{array}{l}\text { C. The system offers detailed explanations of answers to some multiple choice questions which help us understand the } \\
\text { reason of that choice. }\end{array}$ & $48.4 \%$ \\
\hline $\begin{array}{l}\text { B. The system offers feedback and explanations automatically after one finish a model test in it. These guidance helps us to } \\
\text { learn independently afterwards. }\end{array}$ & $44.1 \%$ \\
\hline A. The validity and reliability of the questions is good, considering the exercises are from authentic CET-4 exam paper. & $33.3 \%$ \\
\hline $\begin{array}{l}\text { D. The system keeps record of one's exercises and tests. This enables one to track, understand and reflect upon his/her } \\
\text { learning progress. }\end{array}$ & $29.0 \%$ \\
\hline E. Others (Please specify & $2.2 \%$ \\
\hline
\end{tabular}

In spite of the majority' acceptance and recognition, the system is not without problems. As revealed earlier in Table 9, there were $24.7 \%$ students dubious about the system and deemed it "somewhat helpful" (Choice C). In addition, 20.4\% thought the exercise in Rofall was "not very good" (Choice C, in Table 10). The following table (Table 12) demonstrates some disadvantages of the system.

TABLE. 12

REASONS FOR DISAPPROVAL OF ROFALL

\begin{tabular}{|l|c|}
\hline \multicolumn{1}{|c|}{ Follow-up of Question 3. For those who choose C and D in question 3, the reason is } \\
\hline \multicolumn{1}{|c|}{ Answer } & \multicolumn{1}{|c|}{ Percentage } \\
\hline E. Sometimes I feel confused without teachers' face-to-face explanations available to most of the exercises. & $16.2 \%$ \\
\hline B. There is some spelling mistakes and wrong answers to some questions. & $9.7 \%$ \\
\hline $\begin{array}{l}\text { C. I feel reluctant to do some of the vocabulary-building questions, which are too difficult, take too long to do yet help } \\
\text { little in vocabulary enlargement. }\end{array}$ & $9.7 \%$ \\
\hline G. Some of the questions are not designed in agreement with my learning objectives. & $7.5 \%$ \\
\hline A. The questions are too boring. & $6.5 \%$ \\
\hline F. I couldn't do these questions off campus due to limited access to the internet and computers. & $4.3 \%$ \\
\hline $\begin{array}{l}\text { I. I don't feel motivated to do these exercises, since how much and well I do them has nothing to do with my final score or } \\
\text { credits. }\end{array}$ & $2.2 \%$ \\
\hline H. The Rofall system doesn't have a user-friendly interface. & \\
\hline J. Others (Please specify & $1.1 \%$ \\
\hline D. Nothing can be gained from the questions which are too simple. & $1.1 \%$ \\
\hline
\end{tabular}

The most obvious problem in doing online exercise was the lack of teachers' face-to-face guidance, as Choice E $(16.2 \%)$ in Table 12 shows. Besides, not all of the questions were appropriate for the students' present English proficiency - certain vocabulary questions were considered too difficult (Choice $\mathrm{C}, 9.7 \%$ ) and some were not in agreement with students' learning objectives (Choice G, 7.5\%). The high level of difficulty of these questions was confirmed again from the fact that no one clicked Choice D, which stated that the questions were too simple for learners to gain anything from. The questions in the system were also criticized for typos and mistakes (Choice $\mathrm{B}, 9.7 \%)$ and boring nature (Choice A, $6.5 \%$ ).

What students didn't take as major causes were their own motivation to do these questions, and access to facilities or operational ability to do exercise online, which was reflected in a small proportion (four students) who selected Choice I, $\mathrm{H}$ and $\mathrm{F}$. This shows the students were computer literate and well-prepared for doing exercises online. This fact offers Rofall a promising future as an independent learning management system, as long as it keeps perfecting its questions.

In a summary, despite typos and mistakes, the Rofall system has been widely accepted and has much potential to be used in more contexts of independent learning, thanks to its relatively satisfying practice, advantage in formative assessment (immediate and detailed feedback and keeping track of one's learning process) as well as students' computer literacy.

\section{Comparison between the New Model and the Traditional One in Terms of Popularity}

1. A slightly higher preference for the traditional model

Both the previous teaching model and the new one were acceptable to the students, who somehow showed a slightly higher preference for the previous one. As shown in Table 13, students' approval rate of the new teaching model was $75.27 \%$, a little lower than that of the previous one $78.5 \%$ (three more students). Students' preference on the more teacher-centered approach has posed an interesting question: why didn't the new model get more credit when it has generated better learning outcomes?

The reasons, analyzed first from the students' written comments in the questionnaire and follow-up interview responses, lie in the advantages and disadvantages of both models. As demonstrated in Table 13, the students believed that, although the previous model was boring and hardly satisfying their individual needs in learning, it excelled in clearer objectives which the teacher set for all, more cooperative learning opportunities in class, and informative lecturing in a time efficient manner; while in the new student-centered model, they sometimes felt confused about learning objectives and needed more supervision and guidance in autonomous learning, although this new model provided them with opportunities to learn independently, enhanced their language skills and honed their autonomous learning ability. 
TABLE 13.

APPROVAL FOR BOTH MODELS AND REASONS

What is your opinion on both teaching models?

\begin{tabular}{|l|l|l|}
\hline What is your opinion on both teaching models? & $\begin{array}{l}\text { The Previous Model } \\
\text { (More teacher-centered, one-for-all) }\end{array}$ & $\begin{array}{l}\text { The New Model } \\
\text { (More student-centered, individualized) }\end{array}$ \\
\hline Approval & $78.5 \%$ & $75.27 \%$ \\
\hline Why approve? & $\begin{array}{l}\text { Clear objectives; } \\
\text { Informative and efficient; } \\
\text { Cooperate learning. }\end{array}$ & $\begin{array}{l}\text { Chance to learn independently; } \\
\text { Autonomous learning ability; } \\
\text { Language skills. }\end{array}$ \\
\hline Why disapprove? & $\begin{array}{l}\text { Boring; } \\
\text { Less individualized learning. }\end{array}$ & $\begin{array}{l}\text { Lack of supervision; } \\
\text { Lack of training on learning strategies. }\end{array}$ \\
\hline
\end{tabular}

2. Students' perception and ability of autonomous learning

Why was the new teaching model less popular when it in fact generated better learning outcomes? A further investigation was conducted on students' perception and ability of autonomous learning.

Even after the training on autonomous learning and learning strategies, students still had some misperceptions about autonomous learning. Some students believed the teacher shouldn't intervene in students' autonomous learning, otherwise it wouldn't be real autonomous learning. This argument mistook autonomous learning as a learning free from any supervision and guidance. While in fact, "the objection in learner autonomy is not against the teacher acting as a facilitator, guide, supporter etc but against the teachers directing all students' activities and students being totally dependent on their teachers and being unable to function effectively without the teachers" (Thang, 2009, p. 16).

Another belief held by some students was that the teacher should impart more textbook knowledge, which the final exam assessed. It was expected that the teacher spend more time explaining language points and grammar knowledge. This seems to reveal the students' high dependence on the teacher and textbooks and their inclination of learning for the test, a continuation of learning habit shaped in pre-college education (Wang \& Luo, 2008, p. 170), which was test-oriented and knowledge-based. Students' view of the teacher's role of imparting knowledge can also be traced back to the Chinese tradition of seeing oneself as a part of a "relational hierarchy" (Chang \& Holt, 1994, p. 105). This hierarchy of human relations sets the general context within which we must understand Chinese students' respect for authority and their view of the teacher as the authority figure (Ho \& Crookall, 1995, p.237).

The cultural trait of honoring authority, high dependence on the teacher and the habit of cramming for the test have hindered the students from developing their own autonomous learning ability. One consequence was the students' lack of self-discipline, which was shown in a frank and bold comment: "Since we were allowed to learn English autonomously, I spent most of my time learning other subjects like Physics and Mathematics."

Another factors hindering students' development of autonomous learning ability was their lack of meta-cognitive awareness and strategies. As one of the three categories of learning strategies (O'Malley \& Chamot, 1990, p. 44), meta-cognitive strategies are higher order executive skills that may entail planning for, monitoring, or evaluating the success of a learning activity (Brown et al. 1983). As seen in Table 14,15, and 16, As few as $10.75 \%$ (in Table 16) would detect their problems in learning and make adjustment accordingly; only one third reflected upon their learning strategies (31.18\%, in Table 14), monitored their learning process on their own (34.41\%, in Table 15) and assessed their own learning (33.33\%, in Table 17); about half of them (47.31\%, in Table 14) pondered about learning strategies rarely.

TABLE 14

MONITORING: HOW DO YOU REFLECT ON YOUR LEARNING STRATEGIES?

\begin{tabular}{|l|l|}
\hline Answer & Percentage \\
\hline A. I often reflect on my learning strategies to improve them. & $31.18 \%$ \\
\hline B. I think about my learning strategies rarely. & $47.31 \%$ \\
\hline C. I will think about my learning strategies under the teacher's guidance. & $16.13 \%$ \\
\hline D. I have never thought about reflecting on learning strategies. & $4.3 \%$ \\
\hline E. Others & $2.15 \%$ \\
\hline
\end{tabular}

TABLE 15.

MONITORING: HOW DO YOU REFLECT YOUR LEARNING PROCESS, LIKE COMPARING WHAT YOU HAVE ACHIEVED WITH YOUR LEARNING OBJECTIVES?

\begin{tabular}{|l|l|}
\hline Answer & Percentage \\
\hline A. I often do so. I will change or improve my learning methods once I find I haven't achieved my goals. & $34.41 \%$ \\
\hline B. I will reflect my learning progress after the teacher reminds me to. & $29.03 \%$ \\
\hline C. I will do nothing more than comparing my answers to the correct ones. & $27.96 \%$ \\
\hline D. I have never thought about reflecting on my achievement. & $4.3 \%$ \\
\hline E. Others & $5.38 \%$ \\
\hline
\end{tabular}

TABLE 16.

MONITORING: HOW DO YOU DEAL WITH YOUR PROBLEMS IN LEARNING ENGLISH?

\begin{tabular}{|l|l|}
\hline Answer & Percentage \\
\hline A. I often reflect and detect my problems in learning English and make adjustment accordingly. & $10.75 \%$ \\
\hline B. I often reflect to see if I have problems in learning English. & $19.35 \%$ \\
\hline C. I never think about my problems in learning English unless I meet them. & $68.82 \%$ \\
\hline D. I have never thought about my problems in learning English. & $0.0 \%$ \\
\hline E. Others & $2.15 \%$ \\
\hline
\end{tabular}


TABLE 17.

EVALUATION: HOW DO YOU ASSESS YOUR LEARNING PROGRESS?

\begin{tabular}{|l|l|}
\hline Answer & Percentage \\
\hline A. I often do so. & $33.33 \%$ \\
\hline B. I will think about it carefully after the teacher evaluates my learning. & $31.18 \%$ \\
\hline C. I will evaluate under the teacher's guidance. & $18.28 \%$ \\
\hline D. I will check out the teacher's assessment instead. & $9.68 \%$ \\
\hline E. Others & $8.6 \%$ \\
\hline
\end{tabular}

These results indicate students' weakness in meta-cognitive ability and the importance of learner training, especially on their meta-cognitive strategies. Meta-cognitive strategy plays a key role in autonomous learning (Yang, 2002, p. 29). Without which, learners will lose their directions in learning and therefore miss the opportunities to plan, regulate and reflect on achievements (O' Malley \& Chamot, 1990, pp. 48-49). This argument in part explains why some students felt "confused" and "disoriented" about their learning goals, process and progress. Learners' feeling of dis-orientation was considered one of the disadvantages of the new teaching model.

\section{CONCLUSION}

From the analysis above, we can conclude that individualized instruction based on students' needs analysis and through CALL environments could be a feasible way to improve the efficiency and effectiveness of large classes of Integrated English. In this empirical study, the students' comprehensive mastery of English has been improved, in terms of both language knowledge (vocabulary and grammar) and language skills (reading and listening). The LMS Rofall system was considered helpful in facilitating students' individualized learning with the relatively good questions and immediate feedback mechanism. However, the more student-centered, individualized instruction model was slightly less favored $(75.27 \%)$ compared to the previous more teacher-centered, one-for-all teaching model $(78.5 \%)$. The main reasons, among other things, reside in the advantages and disadvantages of the two models, China's cultural trait of honoring authority, and students' relatively weak autonomous learning ability.

There are several factors that can improve the effect of this more student-centered, individualized teaching model. The most important of all is to improve students' perception of autonomous learning and train them to be better language learners. One's perception about learning and mastery learning strategies determines one's learning outcomes (Wen, 1995; Wu, 2000). Given students' passive learning habit and test-orientation due to previous education and the Chinese culture, special efforts are needed in motivating them to be active autonomous learners and empowering them with appropriate learning strategies, in particular meta-cognitive awareness and strategies, which play a key role in one's growth of autonomous learning ability.

Another crucial facilitator would be the teacher's strict supervision and valid assessment. Even highly motivated students could slack off sometimes and hardly make efforts, let alone the majority of non-English major students who hold mainly extrinsic motives for learning English. The teacher's supervision is still highly necessary within the Chinese context. Formative and summative assessments should be combined and well-structured so as to motivate students' learning in the right directions.

In reality, the implementation of the individualized teaching model requires support outside the classroom. For instance, without much decision-making rights, an ordinary College English teacher could change only the additional teaching materials (not the uniform textbook) and alter slightly the breakdown of evaluation. Yet the decision-making of both teaching content and assessment are prerequisites for carrying out any teaching reforms. Therefore, this reform of in College English teaching calls for understanding and support from the school administration.

With all these conditions met, there would be opportunity to increase teaching efficiency and effectiveness in a large class of Integrated English in China. The ultimate goal, or the utopia of individualized instruction would be "a coherent instructional program that tolerates and nurtures widely divergent goals and accomplishment, a program designed to prepare students for complete control of their own education so that schooling, ultimately, is inseparable from living" (Gibbons, 1970, p. 49).

\section{ACKNOWLEDGMENT}

This paper was made possible through two humanities and social sciences projects-- "Research on Multidimensional Assessment for a Web-based English Audio-video Speaking Course" (12YJA740052), supported by the Ministry of Education in China and "Empirical Study on Sino-American Co-teaching Mode of College English Audio-video Speaking Class (EAVSC)" (2011RC1110) supported by "the Fundamental Research Funds for the Central Universities".

\section{REFERENCES}

[1] Altman, H.B. (1972). Individualised foreign language instruction: Ex uno plura. In H. B. Altman (ED.). Individualising the foreign language classroom: perspectives for teachers. Rowley, MA: Newbury House, 1-14.

[2] Berwick, R. (1989). Needs assessment in language programming: from theory to practice. In: Johnson, R. K. (ed.), The second language curriculum. Cambridge: Cambridge University Press, 52-53. 
[3] Brindley, G. P. (1989). The role of needs analysis in adult ESL program design. In: Johnson. R. K.(Ed.), The second language curriculum. Cambridge: Cambridge University Press, 63-72.

[4] Brown, A. L., Bransford, J. D., Ferrara, R. A., and Campione, J. C. (1983). Learning, remembering, and understanding. In J. H. Flavell and M. Markman (Eds.), Carmichael's manual of child psychology (Vol.3, pp. 77-166). New York: Wiley.

[5] Brown, D. (2001). The elements of language curriculum: A systematic approach to program development. Oxford: Pergamon Press.

[6] Cai, J. G. (2003). Why a thorough reform is necessary on the traditional teaching model of College English. China University Teaching, 1, 25-30.

[7] Cai, J. G. (2005). Thoughts on issues of College English teaching. Foreign Language Teaching and Research, 37(2), 83-90.

[8] Cai, J. G. (2007).Study on the characteristics and solutions of China's College English teaching in a transitional period. Foreign Language Teaching and Research, 39(1), 27-32.

[9] Cai, J. G., \& Xin, B. (2009a).College English Curriculum Requirements: Uniform or Individualized. Foreign Language in China, 2, 4-10.

[10] Cai, J. G. (2009b).From unification to individualization and diversification--retrospect and prospect of College English teaching in three decades. China University Teaching, 3, 82-84.

[11] Chang, H., \& Holt, R. (1994). A Chinese perspective on face as inter-relational concern. In Ting-Toomey, S. (ed.), The Challenge of Facework. (p. 105). Albany: State University of New York Press.

[12] Dai, W. D. (2001). The "time wasting and low effects" phenomenon of foreign language teaching; thoughts and solutions. Foreign Language Teaching and Research, 7, 1-32.

[13] Department of Higher Education. (2007). College English curriculum requirements. Beijing: Foreign Language Teaching and Research Press.

[14] Dickinson, L. (1995). Autonomy and motivation: A Literature review. System, 23(2), 165-174.

[15] Korostoff, M. (1998). Tackling California's class size reduction policy initiative: an up close and personal account of how teachers and learners responded. International Journal of Educational Research, 29, 797-807.

[16] Gibbons, M. (1970). What is Individualized Instruction?. Interchange, 1(2), 28-52.

[17] Hayes, D. (1997). Helping Teachers to Cope with Large Classes. ELT Journal, 51(2), 106-116.

[18] Ho, J., \& Crookall, D. (1995). Breaking with Chinese cultural traditions: learner autonomy in English language teaching, System, 23 (2), 235-243.

[19] Hua, W. F. (2009). On foreign language learning motives and learner autonomy. Foreign Language research, 1, 57-62.

[20] Iwai, T., Kondo, K., Limm, S. J. D., Ray, E. G., Shimizu, H., and Brown, J. D. (1999). Japanese language needs analysis. Retrieved August 2, 2012, from University of Hawai'i at Manoa, Web site: http://www.nflrc.hawaii.edu/Networks/NW13/NW13.pdf.

[21] Jin, G. (2007). Discussion on the Problems Existing in the Multimedia English Teaching in a Large Class and the Countermeasures. Sci-tech Information Development \& Economy, 17(25), 252-254.

[22] Li, X. M., \& Sun, D. H. (2008). Empirical Studies on English Autonomous Learning. Journal of Changchun Normal University (Humanities and Social Sciences), 27(2), 132-136.

[23] Liu, R.Q. (2003). On English teaching reform of higher institutions II. Foreign Language Teaching and Research, 3, 221.

[24] Lv, F. \& Wang, L. (2003). Increase the Teaching Effect of Large Class of College English by Improving Learners' Meta-cognitive Awareness. Journal of Shaanxi Normal University, 32 Sup., 13-16.

[25] Lu, Z. H., Li, P. \& Du, P. F. (2009). Interactive Patterns in an English Audio-Video Speaking Class in CALL Environments. International Journal of Pedagogies and Learning, 5(2), 49-65.

[26] Nan, C. (2006). The optimal design of big class of Intensive Reading in CALL environments. China Water Transport. (6) 10, 231-232.

[27] Ni, C.B. \& Liu, Z. (2006).Properties of Needs for a Foreign Language. Foreign Languages and Their Teaching 2, 21-24.

[28] O' Malley, J.M. \& Chamot, A. U. (1990). Learning strategies in second language acquisition. London: MacMillan.

[29] Pang, H. C. (2006). A Study of Online Teaching Mode for Large Class of College English. Unpublished master's thesis, Guangxi Normal University, Guangxi, China.

[30] Sheng,Y. (1990). Principles of Language Teaching. Chongqing: Chongqing publishing house.

[31] Skinner, B.F. (1968). The Technology of Teaching. New York: Appleton-Century-Crofts.

[32] Shu, D.F. (2004). FLT in China: Problems and suggested solutions. Shanghai: Shanghai Foreign Language Education Press.

[33] Tan, Q. \& Qiu, J. (2008). Fostering students' autonomous learning ability in large class of English. Continue Education Research. 5,170-171.

[34] Thang, X. M. (2009). Investigating the Learner Autonomy of Malaysian ESL Learners: Towards a Redefinition. In Thang, X. M., \& Sinclair, B. (Eds.), Learner Autonomy: Research and Practice in Malaysia and Singapore. (pp. 16-17). Selangor Darul Ehsan, Malaysia: Pearson Longman.

[35] Volman, M. (2005). A variety of roles for a new type of teacher Educational technology and the teaching profession. Teaching and Teacher Education 21, 15-31.

[36] Wang, M. C., \& Finn, J. D. (Eds.). (2000). How small classes help teachers do their best. Philadelphia, PA: Temple University Center for Research in Human Development in Education.

[37] Wang. M. L. (2009). An Experimental Study of Interactive Teaching in Large Task-Based College English Classes. Unpublished master's thesis. Ocean University of China, Shandong, China.

[38] Wang, J. X., Wang, X.S., Ma, J., Jia, H.M., Xu, J., Li, X. L., Shi, H. W., \& Lu, Z. H. (2003).An teaching experiment of large class of Intensive English using multimedia. Foreign Language Teaching and Research 35(5), 365-371.

[39] Wang, J., \& Yan, X. Q. (2011). An overview of research on large class of College English in recent decade. Education Research Monthly. 11, 105-106.

[40] Wang, L. (2009). The Comparison of the Teaching Effects in Big Class between the Multimedia-Assisted Classroom and the Traditional One. Computer-Assisted Foreign Language Education in China, 5, 75-79. 
[41] Wang, L. F. \& Luo, S. M. (2008). On the constraints in developing of college students' English autonomous learning ability. Heilongjiang Research on higher education, 3, 169-172.

[42] Weaver, S.J. \& Cohen, A.D. (1997), Strategies-based Instruction: A teacher-training manual. CARLA Working Paper Series \#7. Minneapolis, MN: University of Minnesota, The Center for Advanced Research on Language Acquisition.

[43] Wen, J. (2003). On the advantages and disadvantages of large class teaching of English and the use of communicative language teaching. Journal of Beijing International Studies University, 6, 75-78.

[44] Wen, J (2004). On the study of translation curriculum. Journal of Foreign Languages 3, 64-70.

[45] Wen, Q. F. (1995).The differences between successful English learners and less achieving English learners in learning methods. Foreign Language Teaching and Research, 3, 61-66.

[46] Wikipedia. (2012). Individualized Instruction. Retrieved August 2, 2012, from http://en.wikipedia.org/wiki/Individualized_instruction

[47] Yalden, J. (2000). Principles of Curriculum design for Language Teaching. Beijing: Cambridge University Press.

[48] Wu, H. Q. (2011). A Probe into Autonomous Learning in Tertiary Large Class English Teaching. Journal of Higher Education Finance, 2, 56-59.

[49] Wu, H.P. (2000). The relationship between Meta-cognition and Foreign Language Learning. Foreign Language Teaching Abroad, 2, 14-19.

[50] Xiao, F. (2010). An Empirical Study on a Comprehensive Teaching \& Learning Approach in Large College English Class-Based on Management Theory. Foreign Language in China, 7(1), 10-12.

[51] Xu, A.J. (2007). Problems and Solutions in Large English Class. Journal of University of International Relations, 4, 57-62.

[52] Xu, J. F. (2011). Problems and Solutions of China's College English Teaching. Contemporary Foreign Language Studies, 10, 26-31.

[53] Yang, W. Y. (2002). Integration of meta-cognition training in English teaching. Foreign Languages and Their Teaching, 2, 2829.

[54] Yu, J.Q. (2004). Problems and Solutions in Large Class of College English. Journal of Chongqing University of Posts and Telecommunications (Social Science Edition,3, 139-140.

[55] Yuan, X. M. (2003). EFL's big class and cooperative learning. Journal of Shaanxi Normal University (Social Science), 32 Sup., 207-209.

[56] Zhang, S. F. (2007). The Application of Multimedia/Net-based CL in Large English Classes, Journal of Beijing University of Chemical Technology (Social Science), 2, 70-74.

[57] Zhang, Y. (2003). Individualized instruction: the classic principle of teaching. Journal of Shandong Education Institute, 1, $102-108$.

Ping Li was born in Weifang, Shandong Province in 1982. She received her M. A. degree of Foreign Linguistics and Applied Linguistics at Nankai University, Tianjin, China in 2007.

She is currently a Lecturer in School of Humanities, Beijing University of Posts and Telecommunications, Beijing, China. Her research interests include computer-assisted language learning, English language teaching and translation \& interpretation.

Zhihong Lu was born in Urumchi, Xinjiang Uyghur Autonomous Region in 1963. She received her B. A. degree of English Education from Capital Normal University, Beijing, China in 1985. She attended the Graduate Training Program at Beijing Foreign Studies University during 1993-1994, specializing in applied linguistics.

She is currently a Professor and Supervisor of master students in School of Humanities, Beijing University of Posts and Telecommunications, Beijing, China. Her research interests include applied linguistics, especially, computer-assisted language learning, language teaching, and sociolinguistics. 